\title{
A fotografia humanista e a construção de uma historiografia sobre a fotografia latino-americana
}

\author{
Humanist photography and the formation of a historiography \\ on Latin-American photography \\ La fotografía humanista y la construcción de una historiografía de la \\ fotografía latino-americana
}

ErikaZerwes ${ }^{*}$

\section{Resumo}

Este artigo busca analisar, de forma paralela, alguns aspectos da construção de uma historiografia da chamada fotografia humanista e da fotografia latino-americana. Ambas começam a se constituir de forma mais articulada em finais da década de 1970 e início da década de 1980. Assim, mais do que discutir produções fotográficas específicas, o objetivo é debater os modos como essas produções foram articuladas em discursos que buscaram unificá-las. Trata-se da sistematização de conclusões preliminares de uma pesquisa ainda em andamento sobre as diferentes noções de humanismo na fotografia e como se manifestam na fotografia latino-americana.

Palavras-chave: Cultura visual. Fotografia humanista. Fotografia latino-americana.

\section{0 humanismo na fotografia francesa}

A crítica costuma localizar o aparecimento de uma significativa quantidade de fotografias com estética e temática associadas a um caráter humanista durante a década de 1930, na França - mais especificamente na imprensa ilustrada francesa durante os anos da Frente Popular. ${ }^{1}$ Essa vertente fotográfica, denominada de fotografia humanista, ganhou força na França após a Segunda Guerra Mundial.

Doutora em História pela Universidade Estadual de Campinas, Brasil. E-mail: erika-zerwes@gmail.com

Recebido em 01/04/2016 - Aprovado em 01/09/2016 http://dx.doi.org/10.5335/hdtv.16n.2.6920 
Ao final da guerra, a França estava destruída fisicamente, tendo sofrido maciças perdas de vidas, militares e civis, e experienciado anos de combates entre as forças de ocupação nazista, as de resistência interna e as dos Aliados após a invasão de 1944. Mais do que essa destruição, no entanto, a França também vivia a cisão simbólica de um passado republicano fortemente associado aos ideais de civilização e aos quatro anos do governo do marechal Pétain, autoritário e conivente com os princípios nazistas, entre eles, a perseguição e o assassinato de judeus. A França, portanto, acabava de sair de quatro anos de colaboração direta com os alemães, do governo de Vichy, ao mesmo tempo em que buscava seu lugar de direito na mesa de negociações ao lado dos vitoriosos Aliados contra a Alemanha derrotada (SULEIMAN, 2006, p. 14).

Tanto a destruição física quanto essa cisão simbólica foram aspectos presentes em uma tentativa de reconstrução da França no imediato pós-guerra, quando um discurso de cunho humanista predominou. A reconstrução social e política surgiu então na forma de uma união entre esquerda e direita em torno de certos valores consensuais, descritos pelo vitorioso general francês De Gaulle como pertencentes ao "bem comum" contra a "coalisão de interesses que pesaram tanto nas condições dos homens", em que o Estado francês assegurasse, finalmente, que "cada um de seus filhos e filhas possam viver, trabalhar, criar seus filhos com segurança e dignidade"2 (apud HAMILTON, 2007, p. 93, grifo nosso).

Esses mesmos valores podem ser observados no trabalho de fotógrafos atuantes na França, e em especial em Paris, no fim da década de 1940. Tanto seus discursos, quanto as temáticas universalistas de suas fotografias, gravitavam em torno da vida cotidiana das pessoas comuns, de anônimos, geralmente no ambiente urbano: a família, as crianças e a infância, a comunidade e a camaradagem, o amor e os amantes. A tentativa de reconstrução da cisão simbólica no pós-guerra envolveu assim a fotografia, por meio de uma representação do que seria a própria França e seus "filhos e filhas". Animada pelos ideais defendidos por De Gaulle, essa fotografia, que mais tarde seria associada a um movimento denominado humanista, elaborou um léxico visual e uma coleção de símbolos relativos a Paris, aos parisienses e aos franceses em geral (BEAUMONT-MAILLET, 2006, p. 13). Tal uso da fotografia para a reconstrução simbólica - que não se limitou apenas ao interior do país, mas que também teve abrangência internacional - fica claro quando se vê que boa parte desses fotógrafos trabalhavam para o Comissariado-Geral do Turismo e para o Serviço de Documentação francês. Entre 1946 e 1960, o Estado francês foi um dos contratantes de fotógrafos, franceses e de estrangeiros atuantes no país, que compartilhavam dessa visão humanista, como Robert Doisneau (1912-1994) e Willy Ronis (1910-2009). O Comissariado do Turismo incentivava-os a fazer imagens "vivas, alegres, animadas, contrastadas, caraterísticas da França e de suas riquezas infinitas, mas também de seu equipamento turístico" (HAMILTON, 2007, p. 28), com a intenção de que fossem publicadas no exterior. 


\section{A internacionalização da fotografia humanista}

Uma cultura política similar à encontrada na França, baseada na reconstrução do país por meio de um consenso quanto aos valores humanistas, também foi se consolidando em todo o Ocidente ao final da Segunda Guerra Mundial, contemporânea à criação de organizações internacionais, como ONU e Unesco, (1945), OMS e Unicef (1947), bem como à Declaração Universal dos Direitos Humanos, estabelecida pela ONU em 1948. Paralelamente a essa cultura política, uma cultura visual tributária do humanismo também floresceu internacionalmente - tornando-se o que o historiador da fotografia Peter Hamilton chamou de paradigma representacional humanista (HAMILTON, 2007, p. 78-80). Deixando de lado algumas das especificidades francesas, a corrente humanista que se formava na fotografia espalhou-se internacionalmente por meio dos fotógrafos atuantes na França, mas também por meio das agências fotográficas e das revistas ilustradas, que já então possuíam um alcance internacional bem considerável. Agências, como a Magnum, mantinham fotógrafos atuantes em vários países simultaneamente.

Desde sua fundação, em 1947, a Magnum praticou uma fotografia associada às temáticas universais humanistas. Seus membros, entre eles Robert Capa (19131954), Henri Cartier-Bresson (1908-2004) e David Seymour "Chim" (1911-1956), estavam proximamente associados ao início e ao desenvolvimento da fotografia humanista na França antes e depois da Segunda Guerra Mundial (ZERWES, 2014, p. 159-177). En- tendida como uma linguagem compreensível universalmente, e praticada com essa finalidade, a Magnum buscou vender suas reportagens para as massas de leitores das revistas ilustradas da época, que, como era o caso da estadunidense Life, atingiam dezenas de milhões de leitores nos anos de 1940 (HAMILTON, 2007, p. 143-144).

O trabalho histórico sobre a fotografia humanista enquanto corrente fotográfica, para além das monografias sobre fotógrafos individuais, é de certo modo recente. Grande parte dele concentra-se na relação entre a fotografia humanista e a exposição The Family of Man, realizada no MoMA, o Museu de Arte Moderna de Nova Iorque, em 1955, por Edward Steichen, e em uma tradição crítica iniciada com a análise que Roland Barthes fez da exposição quando ela foi apresentada na França, publicada em 1957 no livro Mitologias (2003, p. 175-178). ${ }^{3}$ No entanto, como se verá, apenas no início da década de 1980 estudos mais articulados sobre esse movimento fotográfico começaram a ser publicados, em primeiro lugar na França, e depois em outros países da Europa e nos Estados Unidos.

Ao deixar a França, após a Segunda Guerra Mundial, o termo fotografia humanista tornou-se ainda mais impreciso, servindo para designar um movimento fotográfico internacional, cuja relevância dentro da história da fotografia é tão grande quanto a imprecisão de seus contornos e sua abrangência conceitual. De modo geral, podemos encontrar na bibliografia uma afirmação dessa imprecisão conceitual, e assim, a mesma crítica que vê esse movimento aflorar na década de 1930, encontra dificuldade em 
circunscrevê-lo tanto em suas manifestações na França quanto no exterior. Em 1983, o escritor francês Claude Nori, falando sobre as origens da fotografia humanista, denomina-a de "realismo poético" e a aproxima claramente do momento político vivido durante a Frente Popular e outros movimentos artísticos e culturais que dialogavam com aquele momento:

O realismo poético, antes de ser um movimento ou uma escola artística, é um ambiente no qual se manifesta de 1936 a 1944 um humanismo tipicamente francês, que tem suas raízes nos ideais generosos da Frente Popular. A fotografia, bem como a literatura, o cinema, ou a música, têm um papel importante e atuam como pano de fundo, de decoração poética, para uma ideologia que configura valores tradicionais e sentimentais do homem (1983, p. 19).

A francesa Marie de Thézy, em uma monografia sobre o Grupo dos XV francês, tratou, também em 1983, sobre a internacionalização dessa fotografia, que trazia em si os ideais do discurso de De Gaulle ao final da guerra. Segundo ela, "essa necessidade calorosa de reencontrar o homem em sua dignidade profunda é um fenômeno internacional" (1983, p. 43, grifo nosso). Já em 1992, como chefe de conservação da Biblioteca da Cidade de Paris, ela publicou, em uma das primeiras tentativas de historicizar como um todo a fotografia humanista em sua manifestação francesa, o livro La photographie humaniste: 1930-1960, histoire d'un mouvement en France. Ela abre o livro com uma nota ao leitor, uma espécie de esclarecimento sobre a noção de humanismo utilizada na obra. Segundo ela, haveria duas concepções diferentes, uma referente a uma tradição greco-lati- na e cristã, bastante ampla, em que o homem é a medida de todas as coisas, e uma segunda concepção, mais restrita às imagens, que dizia respeito à fotografia que "tem por assunto o ser humano, e a marca que ele deixa na natureza e sobre as coisas", bem como que chamaria atenção "para a pessoa, a todos os seres que, ao redor do mundo, possuam em comum este bem inestimável, a natureza humana [...]" (1992, p. 14).

Uma década depois, a Biblioteca Nacional da França sediou uma exposição e publicou um livro sobre o movimento da fotografia humanista. No livro, Laure Beaumont-Maillet afirma claramente a dificuldade tanto de definir o que seria essa fotografia humanista quanto circunscrever sua atuação e fixar limites cronológicos. Ao apresentar uma tentativa de definição, ela o faz de modo bastante amplo e novamente temos presente a noção de "dignidade humana". Segundo ela, "A expressão 'fotografia humanista' designa uma corrente que privilegia a pessoa humana, sua dignidade, sua relação com o seu meio" (BEAUMONT-MAILLET, 2006, p. 11, grifo nosso). Ao mesmo tempo, a autora afirma contundentemente que o humanismo foi, ao lado do pictorialismo, um dos raros movimentos que tiveram impacto na fotografia internacionalmente, e como um todo (BEAUMONT-MAILLET, 2006, p. 11-12).

Tal afirmação, no entanto, pode ser matizada. Em um artigo sobre Robert Doisneau, Nina Lager Vestberg chama a atenção para a falta de uniformidade, ou mesmo constância, que poderia dar à fotografia humanista um caráter mais específico, que a classifique como categoria única. Em especial, falta uma 
categorização que possa unir as fotografias identificadas com o movimento humanista em suas manifestações em diferentes espaços geográficos. Segundo a autora, "nós deveríamos ter cautela ao usar a fotografia humanista ela própria como uma categoria universal, sem dar atenção suficiente para as suas inflexões locais" (VESTBERG, 2011, p. 137) - ao que acrescentaríamos também as inflexões temporais: é possível ver diferenças nas próprias concepções de humanismo conforme as décadas foram passando.

Assim, a fotografia humanista - enquanto uma estética voltada para a fotografia documental, em preto e branco, geralmente feita com câmeras $35 \mathrm{~mm}$, e também enquanto uma ética no que se refere às temáticas universais e a certa preocupação dos fotógrafos com a "dignidade humana" como postulada no discurso de De Gaulle - chegou a impactar a história da fotografia nas regiões mais diversas do globo, inclusive na América Latina, onde teve papel fundamental na construção de uma historiografia da fotografia latino-americana. Nesse caso específico do subcontinente, acreditamos, como se verá, que a noção de fotografia humanista foi unida a estereótipos ou temáticas que tradicionalmente caracterizaram a região, com o intuito de inseri-la dentro de um discurso próprio da historiografia da fotografia europeia e estadunidense. Não obstante, ela faz pare do discurso de alguns dos próprios fotógrafos da região e impactou certamente a nascente historiografia da fotografia latino-americana.

\section{A fotografia humanista e a América Latina}

Pode-se considerar que uma das primeiras aparições da noção de "fotografia latino-americana", articulada de um modo mais consistente, deu-se em 1978, com a realização do Primer Coloquio Latinoamericano de Fotografia, na Cidade do México (CONSEJO MEXICANO DE FOTOGRAFIA, 1978a). Tal noção, e sua consequente historização, são, portanto, ainda mais recentes do que o processo de historização da noção de fotografia humanista. É possível identificar, no entanto, que desde os seus primeiros momentos, a noção de fotografia latino-americana surgida no final da década de 1970 tem significativas ligações com a fotografia humanista.

O fotógrafo mexicano Pedro Meyer (1935), membro do Consejo Mexicano de Fotografia e um dos principais organizadores do primeiro colóquio, reconhece alegremente o papel fundamental desse evento na construção da ideia de uma unidade na produção fotográfica realizada dentro dos limites territoriais latino-americanos. Relembrando, em 2004, as intenções que o levaram a fazer parte da organização desse Primer Coloquio, Meyer deu uma declaração bastante autocongratulatória, ao afirmar que "a fotografia latino-americana nasceu na cidade de Nova York", em 1976 (apud VILLARES FERRER, 2016, não paginado). Naquele ano, Meyer estava na cidade estadunidense para divulgar seu trabalho e, segundo ele, procurar uma interlocução visual e profissional. Seu primeiro destino havia sido justamente o MoMA, uma instituição 
historicamente bastante ligada à fotografia, e mais ainda à produção historiográfica sobre a fotografia. ${ }^{4}$ Sem conseguir a recepção que desejava, Meyer dirigiu-se então ao International Center of Photography (ICP), instituição que havia sido fundada dois anos antes por Cornell Capa (1918-2008) naquela mesma cidade.

Meyer recorda-se que, nesse encontro, Capa mostrou-se menos interessado em suas fotografias do que em saber mais sobre o estado em que se encontrava a fotografia na América Latina. Meyer lembra que o então diretor do ICP perguntara-lhe:

\section{Você conhece outros fotógrafos em outros países da América Latina? Não, eu tive que lhe responder, e assim terminamos a reu- nião onde não pude responder a nada do que, ao que pareceu, era o seu interesse, e o motivo pelo qual tinha me recebido, que era saber sobre a fotografia na América La- tina (MEYER, apud VILLARES FERRER, 2016, não paginado).}

Segundo as afirmações de Meyer, esse encontro teria chamado então a atenção para a falta de conhecimento, entre os próprios fotógrafos da região, sobre o que era produzido na América Latina, o que teria levado o mexicano a participar da organização de um colóquio sobre o assunto e assim teria possibilitado a consolidação de uma noção de "fotografia latino-americana".

Ainda que as lembranças de Meyer pareçam-nos carregadas de exageros, é possível perceber que Cornell Capa e o ICP realmente tiveram papel importante no Primer Coloquio Latinoamericano de Fotografia, no qual Capa foi um dos convidados de honra e um dos poucos participantes de fora da América Latina.
Cornell Capa era um fotógrafo húngaro de ascendência judaica que, assim como seu irmão Robert Capa, imigrou para os EUA na década de 1930, mais tarde tornando-se cidadão estadunidense. Trabalhou como fotógrafo da revista Life na década de 1940 e, após a morte de seu irmão, foi também presidente da agência Magnum até 1960. Durante o final da década de 1960, Cornell começou a organizar um arquivo chamado Fund for Concerned Photography, com as imagens de seu irmão e de outros fotógrafos ligados diretamente ao movimento da fotografia humanista francesa e internacional, como Chim e Werner Bischoff (1916-1954). Esse fundo, que em 1974 se transformou no ICP, era dedicado "à fotografia que demanda envolvimento pessoal e interesse [concern] pela humanidade" (CAPA, 1968, não paginado). Assim, a importância do papel do ICP e de Capa para a realização do primeiro colóquio parece-nos significativa, pois tanto a instituição quanto o fotógrafo têm uma forte ligação com a fotografia humanista e com a manutenção de sua tradição.

Da mesma forma, o ICP foi fundado com a intenção de ser um espaço que abrigasse os arquivos de alguns fotógrafos, de ser um espaço expositivo e de ensino, promovendo a formação em fotografia. Esse tripé também aparece na estrutura do colóquio, que foi organizado tendo por base três grandes eixos. O primeiro foi a exposição de fotografias dos convidados e de fotógrafos selecionados por uma convocatória internacional - cujo catálogo foi publicado com o nome de Hecho en latinoamerica (CONSEJO MEXICANO DE FOTOGRAFIA, 1978b). O segundo eixo consistiu-se de ponencias, ou 
falas de fotógrafos e intelectuais convidados, tratando da história, da crítica e da prática fotográfica na região, que foram publicadas em um volume chamado Memorias del Primer Coloquio Latinoamericano de Fotografía (CONSEJO MEXICANO DE FOTOGRAFIA, 1978a). Por fim, a terceira parte do evento foi dedicada a oficinas, ministradas por vários desses fotógrafos convidados.

Cornell Capa participou da exposição com duas fotografias, que estão no catálogo, ministrou uma das oficinas e proferiu uma das palestras mais polêmicas do colóquio. Intitulada A fotografia social: testemunho ou clichê, sua fala e os dois comentários a ela, um da fotógrafa argentina Alicia D'Amico (1933-2001) e outro do fotógrafo mexicano Nacho López (1923-1986), foram publicados no volume com os anais do colóquio (CONSEJO MEXICANO DE FOTOGRAFIA, 1978b, p. 29-42). O ponto central da polêmica entre os três fotógrafos foi justamente a defesa de uma ética ligada ao fazer fotográfico humanista.

Cornell afirmou que esteve na América Latina fotografando a região quando trabalhava para a revista Life, entre 1952 e 1964, e seguiu falando sobre as pessoas anônimas, pertencentes aos diferentes povos latino-americanos, que ele fotografou quando aqui esteve. Ele conclui sua fala reforçando a inclinação humanista de seu fazer fotográfico:

O que motivou tudo isso, compartilhar o conhecimento de um mundo situado além da compreensão da maioria, despertando consciências e soando o alarme sobre perigos avistados, mostrando a condição humana? A compreensão do que significa ser um verdadeiro testemunho; e a importância do meu papel foi justamente essa.
Eu realmente espero, ainda que não tenha certeza, que todo o trabalho que realizei tenha transformado ou melhorado a vida de muitos. O que eu sei, é que contribuiu para o conhecimento do nosso tempo, tornando possível que o homem sinta mais a vida sobre este planeta que chamamos nosso lar (CAPA, 1978b, p. 30).

A fala de Capa defendeu, assim, o olhar socialmente engajado, embora bastante impreciso politicamente. Alicia D'Amico criticou abertamente a noção do que seria fotografia social para Capa, estendo-a também para outras formas que não o fotojornalismo, afirmando que todas elas dão um testemunho e não são isentas de ideologia. Já o comentário de López foi ainda mais incisivo contra a fala humanista de Capa. Segundo o fotógrafo mexicano:

Este credo idealista é próprio dos "humanitários" generosos que baseiam a conduta na moral burguesa imperante, mas não se comprometem em tomar uma direção ideológica definida. Para eles, tudo se reduz à boa vontade, sem levar em conta que o homem se move no campo das contradições que surgem da luta de classes. Posar como humanitário e liberal é uma posição muito cômoda (LÓPEZ, 1978b, p. 38).

A crítica de López ao humanismo de Capa segue então a tradição crítica iniciada por Barthes na década de 1950, mencionada anteriormente. Depois desse primeiro parágrafo do comentário, López segue fazendo uma crítica bastante longa à cultura fotográfica contemporânea em geral, terminando por esboçar uma definição da característica de testemunho que ele defendia para a fotografia documental. O curioso, no entanto, é que o parágrafo final de sua fala, indo na contramão daquele inicial, converge clara- 
mente para os ideais da fotografia humanista. Segundo ele:

Esta fotografia de testemunho [...] é uma contribuição original cujo autor tenha testemunhado um fato, tenha atestado uma verdade como um denominador comum a todos os seres humanos; uma verdade que irradia uma vivência social e cultural. [...] A função primordial da fotografia, eu acredito ferventemente, é aquela que serve melhor às lutas vitais dos povos, e ao homem na afirmação de sua dignidade (LÓPEZ, 1978b, p. 38).

Como já foi visto, a referência à "dignidade humana" é uma das principais características presentes de forma constante no discurso humanista na fotografia, desde sua origem na França, nos anos 1930. As falas desse primeiro colóquio indicam, como afirma Rosa Casanova (2015, p. 94), inconsistências e discrepâncias ideológicas, que apontam para uma imaturidade no debate sobre a atividade fotográfica na América Latina. No entanto, essas falas também indicam a força da fotografia humanista, expulsa, na fala de López, pela porta da frente, mas trazida de volta pela janela.

\section{A fotografia latino-americana pela visão europeia}

Em 1981, apenas três anos após a realização desse primeiro colóquio, aconteceu no Museu Kunsthaus, em Zurique, a primeira exposição de fotografia latino-americana - entendida como a noção discutida acima, como uma unidade - realizada na Europa. Concebida e realizada pela curadora alemã Erika Billeter (1927-2011), a exposição e seu catálogo, ambos intitulados Fotografie Lateinamerika: von 1860 bis heute, tiveram profunda ligação com o primeiro colóquio. Billeter esteve no México pesquisando na coleção reunida naquela ocasião, formada pela doação das imagens participantes da exposição Hecho en Latinoamerica, e que até hoje se constitui como um dos principais arquivos sobre o assunto. Da mesma forma, não só muitos dos fotógrafos participantes de Hecho estão presentes na exposição e no catálogo montado por Billeter, como também autores de ponencias contribuíram com texto para o livro-catálogo. Em especial, podemos citar a argentina Alicia D'Amico, que falou sobre a fotografia em seu país, e o brasileiro Boris Kossoy, cujo texto falava sobre a pesquisa que revelou a descoberta isolada da fotografia no Brasil por Hercules Florence e assim reivindicava um lugar de relevância para o subcontinente na história da fotografia (BILLETER, 1981, p. 19-30).

Essa primeira experiência levou Erika Billeter a desenvolver sua pesquisa sobre a fotografia do subcontinente e, em 1993, ela publicou pela editora espanhola Lunwerg o livro Canto a la realidad: fotografia latinoamericana 1860-1993. Essa segunda iniciativa de Billeter baseou-se na pesquisa que ela havia feito para a exposição, ou seja, era também devedora do Primer Coloquio Latinoamericano de Fotografia, a autora chega a citar na íntegra a carta de intenções que a fotógrafa brasileira Claudia Andujar havia enviado para o júri do colóquio junto com suas imagens - fotografias de índios yanomami - e que estava publicada ao lado de outras cartas de outros fotógrafos como anexo ao volume do catálogo (BILLETER, 1993, p. 61). 
Esse segundo livro, no entanto, difere-se do livro-catálogo da exposição suíça pela sua temporalidade ampliada em uma década, mas também - e principalmente - porque todo o texto é de autoria da própria Billeter. Em vez de convidar representantes de alguns dos países com maior visibilidade para expor suas produções e histórias das fotografias, como na primeira publicação, nesta segunda, o texto de Billeter é dividido, em sua maioria, por categorias temáticas elaboradas por ela e tratadas cronologicamente. Essa narrativa cronológica, e não mais dividida por países, deixa entrever seus critérios historicistas e sua vontade de constituir uma historiografia. A importância de Canto a la Realidad como marco fundamental dentro da historiografia da fotografia latino-americana é reconhecida pela citação em vários textos (BARBOSA, 2013, p. 563; BETTINO, 2015, p. 79-80). Nossa pesquisa - em acordo com a escassa, porém crescente bibliografia sobre o assunto - tem revelado que, salvo engano, se trata da primeira tentativa de produzir um discurso que aproxime e unifique a fotografia latino-americana, ou seja, de produzir uma historiografia sobre essa fotografia.

É visível por todo o texto de Billeter que sua tentativa de unificar um discurso histórico sobre a fotografia latino-americana é estabelecida por meio da tentativa de incorporar a narrativa histórica tradicional desse meio, construída dentro do eixo França-Inglaterra-EUA. O livro é dividido em duas partes, uma que vai até a década de 1950 e outra que trata dos "contemporâneos". No caso da primeira parte, o discurso unificador tenta ao longo de todo o texto inserir os pioneiros da fotografia na Améri- ca Latina dentro de movimentos e práticas fotográficas europeias ou norte-americanas. Como exemplo, pode-se citar o trecho de Canto a la realidad, em que Billeter fala sobre o argentino Fernando Paillet (1880-1967). Esse fotógrafo tinha um estúdio na província de Santa Fé, mas tornou-se conhecido por ser um dos pioneiros da fotografia de interiores e com precárias condições de iluminação, quando fez uma série de imagens de trabalhadores e artesãos em seus lugares de trabalho. Billeter afirma de Paillet que:

Se trata de um August Sander avant la lettre, pois as fotografias não se encaixam na categoria clássica do retrato mesmo quando, por vezes, tenham alguma coisa a ver com esta especialidade fotográfica. [...] Se trata dos primeiros espaços interiores fotografados com luz natural que aparecem no Novo Mundo. Só são comparáveis às fotografias de Jacob A. Riis (1849-1914), quem já em 1888 fez fotografias no escuro [...] (BILLETER, 1993, p. 27-28).

Da mesma forma, quando a autora na segunda parte do livro tratar da fotografia contemporânea, é justamente a tradição humanista da fotografia documental que ela vai evocar para conferir certa unidade à produção latino-americana, desde os primeiros parágrafos até o final do livro - dos anos 1950 até a última década do século XX, na cronologia histórica lá apresentada.

Assim, quando Billeter discorre sobre fotógrafos tão diferentes quanto o mexicano Nacho López, o brasileiro José Medeiros (1921-1990), a panamenha Sandra Eleta (1942) e o também brasileiro Claudio Edinger (1952), ela o faz a partir de um discurso que aproxima suas imagens e suas intenções àquelas da fotografia humanista (1993, p. 
45, 62-63). De forma sintomática, ela afirma que: "Os autores latino-americanos (talvez os mencionados aqui sejam muito poucos) se sentem motivados por valores éticos e humanos" (1993, p. 62). Tratando especificamente sobre a reportagem fotográfica - na qual o humanismo francês e internacional havia se desenvolvido a partir do pós-Segunda Guerra, e portanto, tinha nesse espaço lugar privilegiado - a autora associa diretamente a fotografia documental de fotojornalistas latino-americanos com a vertente humanista:

O fotojornalismo, ou seja, esse tipo de fotografia utilitária que responde a encomendas diretas, tem destacados representantes em todos os países da América Latina; muitos mais do que poderíamos representar aqui. Deve-se citar, no entanto, a Sandra Bracho (nascida em Caracas), Claudia Gordillo, na Nicarágua, e a Max Hernández, que trabalha como fotojornalista em Honduras. Dada a concepção humanista que inspira a estes fotógrafos, não se pode estranhar que o tema em torno do qual giram as suas reportagens seja o da violência e a guerra. Comunicar a verdade é para eles um desejo pessoal e a expressão de sua atividade profissional (BILLETER, 1993, p. 50).

Em comum, os fotógrafos escolhidos pela curadoria de Billeter, dentre os quais os mencionados, e a narrativa do texto apresentam a fotografia latino-americana a partir de um olhar que corresponde aos elementos que tradicionalmente caracterizaram a região. No trecho citado, aparece mais especificamente uma associação que a autora faz entre a concepção humanista do fotojornalismo subcontinental e a temática da violência e da guerra. Pouco expressivos na fotografia humanista francesa, ainda que subjacentes ao período de reconstrução do pós-guerra, esses temas tiveram maior visibilidade na vertente internacional do movimento fotográfico. Mais do que isso, no entanto, esses temas fazem parte de um conjunto maior que é tradicionalmente associado com a América Latina, que também são abordados por Billeter a partir da chave da fotografia humanista. Assim, podemos ver que Canto a la Realidad privilegia, baseado em um predomínio do documental e do preto e branco, não apenas os temas relacionados à violência, mas também relacionados ao exótico e propostas próximas do realismo fantástico.

Tal privilégio pode ser visto tanto no texto quanto nas imagens selecionadas. A partir de relatos da época, pode-se perceber que esses temas já estavam ressaltados na exposição de 1981. Quando ela foi apresentada em Madri - com o título original bastante objetivo, que em português seria Fotografia Latino-americana, de 1860 até hoje, transformado para o poético El rostro de América Latina en 300 imágenes insólitas - o jornal El País publicou um artigo de autoria de Bel Carrasco, em que esses aspectos já eram ressaltados. $\mathrm{O}$ artigo descreveu a mostra da seguinte forma:

Umas trezentas fotografias, obra de uma centena de autores de diversos países da América Latina, a maioria desconhecidos na Europa, estão dispostas segundo estes critérios [cronológicos] em um labirinto de imagens que são janelas abertas para um mundo em branco e preto em que ganha vida a premente, fantástica, barroca, terrível e comovente realidade latino-americana. Um mundo curioso e alheio, mas reconhecível por meio do que nos contaram os cronistas das Índias, Borges, Gabriel García Márquez, Vargas Llosa e outros narradores do mesmo aparente sonho que é o continente americano (CARRASCO, 1982, não paginado). 
A fotografia humanista em sua vertente internacional, tanto por suas características próprias quanto pela imprecisão e amplitude de suas definições, pôde, na interpretação de Billeter, dar conta de todos esses aspectos da fotografia documental por ela favorecidos. $\mathrm{O}$ humanismo tornou-se assim, sob a pena da autora, uma espécie de bala de prata, capaz de unir as diferentes manifestações da fotografia na América Latina em uma narrativa histórica única e cronológica, compatível com os critérios historicistas e eurocêntricos.

Por um lado, a exposição e o livro foram pensados, produzidos e apresentados fora da América Latina, por uma autora europeia e, nesse sentido, a forte presença do humanismo subjacente à interpretação que a autora fez da fotografia na região seria um indício desse deslocamento. Por outro lado, por ser uma iniciativa de certo modo pioneira, a autora não possuía uma fortuna critica ampliada sobre a qual trabalhar, e imaginamos que ela tenha precisado lançar mão do que tinha ao seu alcance para forjar uma narrativa histórica a partir de indivíduos, práticas e produções fotográficas tão díspares como as produzidas dentro da região. Nesse sentido, é bastante significativo que ela tenha encontrado nessa fotografia tanta abertura para tal interpretação impregnada da tradição humanista.

\section{Considerações finais}

A noção de "fotografia latino-americana" certamente não é algo natural, existente apenas devido a fronteiras e geografias, mas, sim, uma construção histórica. É possível acompanhar seu surgimento, enquanto movimento internacional e conceitualmente mais articulado, entre o final da década de 1970 e início da década de 1980. Como movimento internacional, um dos marcos iniciais é o Primer Coloquio Latinoamericano de Fotografia, e como noção mais articulada conceitualmente, pode-se dizer que um de seus marcos fundamentais seja o trabalho de Erika Billeter. Em ambos os casos, existem referências concretas à estética e aos ideais da chamada fotografia humanista. Tal movimento fotográfico também passou a ser objeto do trabalho histórico no mesmo período - período em que, não coincidentemente, é visível uma valorização da fotografia como meio artístico pela crítica e pelo mercado.

As associações entre a fotografia latino-americana e o humanismo certamente necessitam ainda de mais demoradas investigações. Acreditamos, no entanto, que ao refazermos um percurso bibliográfico pela produções críticas que buscaram produzir uma narrativa histórica unificadora de ambas as fotografias, seja possível levantar algumas relevantes questões para um estudo da historiografia dessa fotografia subcontinental. Pode-se ressaltar que, em comum com o movimento que começou na França, e depois se internalizou, as diretrizes do colóquio e a interpretação de Billeter sobre a fotografia latino-americana ressaltam o papel dos fotógrafos como autores $^{5}$ (BILLETER, 1993, p. 13; CASANOVA, 2015, p. 94). No que diz respeito àquilo que esses fotógrafos registraram, é possível encontrar na fotografia latino-americana representada no colóquio do México de 1978 e no trabalho de Billeter uma posição semelhante ao que é enfatizado por Peter Hamilton na fotografia humanista, quando se desloca da classe ouvrière, ou operária, para se focar na 
classe populaire, ou popular (HAMILTON, 2007, p. 93). É justamente nessa classe popular que tanto a fotografia humanista francesa quanto a fotografia latino-americana, como elaborada naquele momento, vão encontrar certos desvios, um humor, ou então um leve estranhamento, que lhe são particulares: $o$ realismo mágico como descrito por Nori na citação reproduzida no início deste artigo, ou o realismo fantástico encontrado pela reportagem do El País na exposição de Billeter. Acreditamos, portanto, que as escolhas curatoriais e os discursos construídos com elas por Billeter, assim como os discursos produzidos na ocasião do Primer Coloquio, são de grande consequência para historiografia da fotografia latino-americana - do mesmo modo que são também as associações desses discursos com o discurso humanista.

\section{Resumen}

En este trabajo se analiza, de forma paralela, algunos aspectos de la construcción de una historiografía sobre la llamada fotografía humanista, y la fotografía latinoamericana. Ambas comienzan a ser más articulada a finales de 1970 y principios de 1980. Así, en lugar de discutir producciones fotográficas específicas, el objetivo es discutir las formas en que éstas se articulan en discursos que buscaban unificarlas. Se trata de una sistematización de los resultados preliminares de una investigación aún en curso acerca de diferentes conceptos de humanismo en la fotografía, y como se manifiesta en la fotografía latinoamericana.

Palabras clave: Cultura visual. Fotografía humanista. Fotografía latinoamericana.

\section{Abstract}

This article aims to analyse some aspects of the construction of a historiography about the so-called humanist photography, in parallel to the construction of a historiography about Latin-American photography. Both initiatives appeared in a more articulated manner between the end of the 1970s and the beginning of the 1980s. Beyond the discussion of specific photographic productions, the intent is to discuss the ways in which these productions were articulated inside discourses that sought to unify them. This study is a first attempt at systematizing some preliminary conclusions of an on-going research about different notions of humanism in photography, and how they appear in Latin-American photography.

Keywords: Visual culture. Humanist photography. Latin-American photography.

\section{Notas}

1 A tentativa de fazer frente à ameaça fascista que pairou sobre a Europa nos primeiros anos da década de 1930 levou diferentes partidos de esquerda a buscar a união. Chamada de Frente Popular, essa união ganhou proeminência no começo daquela década, na Alemanha, e na segunda metade dos anos de 1930, na França e Espanha. Ver: TARTAKOWSKY, Danielle. Le Front Populaire : la vie est à nous. Paris: Gallimard, 1996.

2 As traduções do espanhol, inglês e francês são da autora.

3 Embora a visão de Barthes seja bastante crítica, ela coloca a exposição como um lugar privilegiado do humanismo na fotografia. A expressão "clímax" é recorrente na bibliografia para caracterizar a associação entre o movimento fotográfico e a cultura política do pós-Segunda Guerra. Jean-Claude Gautrand afirma que: "Without a doubt, the climax of this great idealistic trend was the huge exhibition which Edward Steichen 
organized at the Museum of Modern Art, New York, in 1955, entitled The Family of Man". E, mais à frente, reitera: "The idealism displayed by The Family of Man, coming, as it did, a few years after the Marshall Plan, marks the culmination of humanist photo-reportage" (1998, p. 627-628). Colin Osman relaciona esse clímax também ao início da perda de visibilidade dessa vertente: "The climax of the great humanist and idealist current of photography came with the 'Family of Man' exhibition organized by Edward Steichen in 1955. [...] But, as often happens, the climax also turned out to be the limit; and it is fair to say that the later reaction against 'Family of Man' ushered in the period of truly contemporary photography" (1998, p. 184). Com efeito, tal relação entre a fotografia humanista e essa exposição nos parece inevitável e será, no entanto, tratada em outro momento.

4 Além de ter sediado a exposição Family of Man em 1955, o MoMA também sediou em 1937 a exposição Photography 1839-1937, sob a curadoria de Beaumont Newhall, que deu origem à publicação de um dos primeiros livros, e até hoje um dos mais reconhecidos, sobre a história da fotografia (NEWHALL, 2003).

5 Ainda na introdução de Canto a la realidad, Billeter afirma que "Ya en el siglo XIX fueron destacando temas que, aún hoy, siguen marcando como auténticos leitmotivs la fotografía del continente. Hemos rastreado estos temas en el presente libro. A través de ellos, el continente latinoamericano forma un todo visual apoyado en la fuerza cultural de sus fotógrafos que, como autores, forman el conjunto total. La fotografía en Latinoamérica se ha convertido en una parte de la presencia cultural de dichos países. En correspondencia con la anterior, la estructura social está marcada por ella y por sus autores" (1993, p. 13).

\section{Referências}

BARBOSA, Carlos Alberto Sampaio. Fotolivros e história comparada da fotografia na América Latina: reflexões teóricas e possibilidades de investigação. In: ENCONTRO NACIONAL DE ESTUDOS DA IMAGEM, 4; ENCONTRO INTERNACIONAL DE ESTUDOS DA IMAGEM, 1, 2013, Londrina. Anais... Londrina, 2013. Parte deste artigo foi publicada também em Balance historiográfico de la fotografía latinoamericana a partir de una perspectiva brasileña. Metodologías y ejes de análisis. 2011. Disponível em: <http:/ / www.ungs.edu.ar/cm/uploaded_files/file/ publicaciones/trama/sampaio.html>. Acesso em: 25 jun. 2016.

BARTHES, Roland. Mitologias. Rio de Janeiro: Difel, 2003.

BEAUMONT-MAILLET, Laure. Cette photographie qu'on appelle humaniste. In: BEAUMONT-MAILLET, Laure; DENOYELLE, Françoise (Ed). La photographie humaniste, 1945-1968 autour d'Izis, Boubat, Brassaï, Doisneau, Ronis... Paris: BNF, 2006. p. 11-25.

BETTINO, Carla. Mapas abiertos: fotografía latinoamericana 1991-2002. Lo latinoamericano en el relato sobre la fotografía. Boletín de Arte, Buenos Aires, n. 15, p. 77-84, sept. 2015. Disponível em: <http:/ / papelcosido.fba.unlp. edu.ar/ojs/index.php/boa>. Acesso em: 27 jun. 2016.

BILLETER, Erika (Org.). Fotografie Lateinamerika: von 1860 bis heute. Zürich, Bern: Kunsthaus, Benteli, 1981.

. Canto a la realidad. Madrid, Barcelona: Lunwerg, 1993.

CAPA, Cornell. La fotografía social: testimonio o cliché. In: CONSEJO MEXICANO DE FOTOGRAFIA. Hecho en latinoamérica: Primera Muestra de la Fotografía Latinoamericana Contemporánea. Ciudad de México: Consejo Mexicano de Fotografía A.C., 1978. p. 29-30.

CAPA, Cornell (Ed). The concerned photographer: the photographs of Werner Bischof, Robert Capa, David Seymour, Andre Kertesz, Leonard Freed, Dan Weiner. New York: Grossman, 1968.

CARRASCO, Bel. El rostro de América Latina en 300 imágenes insólitas. El País, Madrid, 11 sept. 1982. Disponível em: <http://elpais.com/diario/1982/09/11/ultima/400543203_850215. html>. Acesso em: 25 jun. 2016. 
CASANOVA, Rosa. Luchas documentales en los "largos setenta". In: RIBALTA, Jorge (Org.). Aún No: sobre la reinvención del documental y la crítica de la moderni- dad. Ensayos y documentos [1972-1991]. Madrid: Museo Nacional Centro de Arte Reina Sofia, 2015. p. 46-103.

CONSEJO MEXICANO DE FOTOGRAFIA. Memorias del Primer Coloquio Latinoamericano de Fotografía. Ciudad de México: Consejo Mexicano de Fotografía A.C., 1978a.

. Hecho en latinoamérica: Primera Mues-

tra de la Fotografía Latinoamericana Contemporánea. Ciudad de México: Consejo Mexicano de Fotografía A.C., 1978b.

DE THÉZY, Marie. Le Groupe des XV : un moment de la photographie française. Les Cahiers de la Photographie, Paris, n. 9, p. 29-45, 1983.

La photographie humaniste, 1930-1960:

histoire d'un mouvement en France. Paris: Contrejour, 1992.

GAUTRAND, Jean-Claude. The family of man. In: FRIZOT, Michel (Org). The new history of photography. Köln: Köneman, 1998. p. 628.

HAMILTON, Peter. Representing the social: France and frenchness in post-war humanist photography. In: HALL, Stuart (Ed). Representation: cultural representations and signifying practices. London, Thousand Oaks, New Delhi: SAGE, 2007.

LÓPEZ, Nacho. Comentario. In: CONSEJO MEXICANO DE FOTOGRAFIA. Hecho en Latinoamerica. Primera Muestra de la Fotografía Latinoamericana Contemporánea. Ciudad de México: Consejo Mexicano de Fotografía A.C., 1978. p. 38-41.

NEWHALL, Beaumont. The history of photography: from 1839 to the present. New York: Museum of Modern Art, 2003.

NORI, Claude. La panoplie photographique du réalisme poétique. Les Cahiers de la Photographie, Paris, n. 9, p. 18-27, 1983.
OSMAN, Colin. Photography sure of itself. In: LEMAGNY, Jean-Claude, ROUILLE, André (Ed). Histoire de la photographie. Paris: Larousse, 1998.

SULEIMAN, Susan Rubin. Crises of memory and the Second World War. Cambridge: Harvard University, 2006.

VESTBERG, Nina Lager. Robert Doisneau and the making of a universal cliché. History of Photography, London, v. 35, n. 2, p. 157-165, May 2011.

VILLARES FERRER, Monica. Hecho en latinoamérica: la invención de la 'Fotografía Latinoamericana'. Sures, Foz do Iguaçu, n. 7, 2016. Disponível em: <https://revistas.unila.edu.br/ index.php/sures/issue/view/25/showToc>. Acesso em: 22 jun. 2016.

ZERWES, Erika. Iconografias de esquerda: encontro entre cultura visual e cultura política em fotografias da Guerra Civil Espanhola. Visualidades, Samambaia, v. 12, n. 2, p. 159-177, jul./dez. 2014. 